\title{
Code Warriors: NSA's Codebreakers and the Secret Intelligence War Against the Soviet Union. By Stephen Budiansky. New York, NY. Borzoi Book, Published by Alfred A. Knopf, Penguin Random House, New York, 2016.
}

Ed Urie

Henley-Putnam University

Follow this and additional works at: https://digitalcommons.usf.edu/jss

pp. 94-95

\section{Recommended Citation}

Urie, Ed. "Code Warriors: NSA's Codebreakers and the Secret Intelligence War Against the Soviet Union. By Stephen Budiansky. New York, NY. Borzoi Book, Published by Alfred A. Knopf, Penguin Random House, New York, 2016.." Journal of Strategic Security 10, no. 3 (2017) : 94-95.

DOI: http://doi.org/10.5038/1944-0472.10.3.1641

Available at: https://digitalcommons.usf.edu/jss/vol10/iss3/7

This Book Review is brought to you for free and open access by the Open Access Journals at Digital Commons @ University of South Florida. It has been accepted for inclusion in Journal of Strategic Security by an authorized editor of Digital Commons @ University of South Florida. For more information, please contact digitalcommons@usf.edu. 
Code Warriors: NSA's Codebreakers and the Secret Intelligence War Against the Soviet Union. By Stephen Budiansky. New York, NY. Borzoi Book, Published by Alfred A. Knopf, Penguin Random House, New York, 2016. 
Code Warriors: NSA's Codebreakers and the Secret Intelligence War Against the Soviet Union. By Stephen Budiansky. New York, NY. Borzoi Book, Published by Alfred A. Knopf, Penguin Random House, New York, 2016. ISBN 978-0--385-352666. Pictures. Graphs. Notes. Appendices. Index. Sources Cited. Pp. xix, 310. \$30.00.

By its title, and especially its subtitle, one would expect this book to be primarily about the National Security Agency, an in-depth history of this major element of the US Defense Department and

Intelligence Community. In fact, the largest portions of the book, and possibly the most interesting, provide detailed information about codes and ciphers, which might be expected, and the many factors, histories, and environments of the Soviet Union, Russia, Vietnam, and both North and South Korea during critical historic periods.

The focus on codes and ciphers, both in the text and in the series of appendices, is detailed and extensive. These portions provide everything from the basic to the most complex analyses of code and cipher technology, ranging from the reasonably simple to the ultimate in complexity. Some of the processes described are of the type that would make a reader want to encrypt any personal financial or other sensitive documents using a described process. Others are so complex that one would expect to have advanced degrees in mathematics and extensive experience in alphabetic manipulation to understand. In either case these descriptions clearly show the potential effectiveness and complexity of the use of codes and ciphers to protect information, as well as their potential weaknesses and vulnerabilities.

The discussions about various geographic areas, nations, and political motivations are wide-ranging, clear, and perceptive. The perspectives of Marxist-Leninist ideologies are clearly and pointedly, described. The information about the order from the 1948 Soviet military administration in Germany that effectively established the wall between East and West Berlin is extremely interesting. The map and information about the flight path of the US Navy PB4Y-2 electronic surveillance plane shot down by the Soviets off the coast of Latvia on April 8, 1950, is especially interesting to those concerned with military events. The author also provides a discussion of events that followed the end of World War II resulting in the Korean peninsula's division into North and South Korea, and which ultimately led to our involvement in the Korean War. Also discussed in good detail are the events leading to and during the Vietnam conflict. 
The author's somewhat detailed review of the emergence of the National Security Agency following code and cipher activities of the World Wars is very attention grabbing, although somewhat misleading. This discussion, and that of NSA in the present time, is clearly based on unclassified, declassified, and open source materials, to which there are frequent and numerous references throughout the text. Most likely the author has never held the high security clearances that would be needed to fully understand the NSA mission, operations, failures, and successes, as he repeatedly makes somewhat false or misleading comments about the objectives and the intentions of NSA operations and people. For example, the author claims that at one period many operations personnel were so disturbed by agency activities that they moved from operations to the personnel organization. According to reliable, fully cleared individuals, this simply did not happen. Such incorrect statements are only representative of an obviously negative view of the National Security Agency apparently inspired by lack of real information on that subject that pervades the book. What is lost is the recognition that keeping sensitive information from the public is a necessity in order to prevent exposure of that information to our enemies.

In short, the book is both interesting and informative in the presentations about codes, ciphers, and national political motivations in history. Regarding the inherent nature of the National Security Agency, though, it is totally incorrect and misleading.

Ed Urie, Henley-Putnam University 